\title{
The Effect of Make a Match Technique on Students' Reading Comprehension at XI Grade of MAN 1 Padangsidimpuan
}

\author{
By: Dr. Fitriadi Lubis, M.Pd., Sojuangon Rambe, S. S., M.Pd., \\ and Annisa Nur Habibie A. R. Harahap
}

\begin{abstract}
ABSTRAK
Penelitian ini difokuskan pada pengaruh teknik Make the Match pada pemahaman bacaan siswa pada kelas XI MAN 1 Padangsidimpuan. Masalah siswa dalam pemahaman bacaan adalah: 1) Sebagian besar siswa masih mendapatkan kelas rendah dengan rata-rata adalah 60. 2) Sebagian besar siswa tidak mengerti teks yang dibaca oleh siswa. Mereka hanya membaca teks tanpa memahami teksnya. 3) Sebagian besar siswa mudah merasa bosan saat mereka belajar tentang teks bahasa Inggris. Selain masalah siswa, teknik guru juga menjadi masalah dalam belajar bahasa Inggris. Guru masih menggunakan pengajaran konvensional dan tidak memiliki variasi dalam pengajaran membaca. Tujuan dari penelitian ini adalah untuk mengetahui apakah ada pengaruh yang signifikan dari teknik Make the Match pada pemahaman bacaan siswa pada kelas XI MAN 1 Padangsidimpuan. Metode yang digunakan dalam penelitian ini adalah penelitian eksperimental. Dua kelas dipilih secara acak sebagai sampel. Mereka adalah XI MIA 3 sebagai kelas eksperimen yang terdiri dari 40 siswa dan XI MIA 4 sebagai kelas kontrol yang terdiri dari 40 siswa. Itu diambil setelah melakukan uji normalitas dan homogenitas. Data tersebut berasal dari pre-test dan posttest. Untuk menganalisa data, peneliti menggunakan rumus t-test. Setelah menganalisis data, peneliti menemukan bahwa rata-rata skor kelas eksperimen setelah menggunakan teknik Make a Match lebih tinggi daripada kelas kontrol. Skor rata-rata kelas eksperimen sebelum menggunakan teknik Make the Match adalah 64,13 dan skor rata-rata setelah menggunakan teknik Make the Match adalah 75,23 dan mengalami kenaikan 11,10. Pengaruh teknik Make the Match pada pemahaman bacaan siswa adalah 3.009 dengan jumlah $t$ hitung lebih tinggi daripada $t$ tabel (3.009> 2.000). Itu berarti Ha diterima dan H0 ditolak. Disimpulkan bahwa ada pengaruh yang signifikan dari teknik Make the Match pada pemahaman bacaan siswa pada kelas XI MAN 1 Padangsidimpuan.
\end{abstract}

\section{Key Words: Make a Match Technique and Reading Comprehension}

\section{A. INTRODUCTION}

Reading comprehension is an ability to understand what the readers read where words have context and text have meaning. If the readers can read the words of a text, but they do not understand what they are reading, they are not really reading. Reading comprehension is an essential skill for English learners. 
Based on the information from Mrs. Afnita Warni, S.Pd as English teacher of MAN 1 Padangsidimpuan as the place of this research, the students in this school are poor ability in reading comprehension. It makes them bad in understanding English text and difficult to recall the information that needed from the text. The students have some problems in reading comprehension, such as difficult to understand of English text, bad pronunciation, spend many times to find out the meaning of word by word, getting bored and tired in reading comprehension. The problems are caused by several reasons such as students' educational background, lack vocabularies, their less practice, interesting and motivation, their bad mindset about English, their less technique to learn reading comprehension and teacher's less technique in teaching. ${ }^{1}$ The researcher thinks that it is a big problem.

There are some factors in students reading comprehension, such as media and technique. Technique is teacher's way to teach a material or everything teachers do or should do in order to help their learners learn with systematic procedure. A teacher must use various techniques in teaching reading comprehension in order to take students' attention and make a learning process become fun. There are many techniques that can be applied in teaching reading comprehension. Some of the popular techniques are Jigsaw technique, Silent reading, Semantic mapping, Skimming, Scanning, Make a match technique and another. Those various techniques are suitable and good for enjoyable teaching learning process in reading comprehension classes.

One of the techniques to teach reading comprehension is Make a Match technique. This reading comprehension teaching technique uses some cards. The cards consist of questions and answer cards. The question and answer cards connected by the material and suitable with the topic or material that taught by researcher or teacher.

Based on the explanation above, the reseracher is interested to introduce Make a Match technique to teach reading comprehension in the school. The researcher wants to know whether Make a Match technique give significant effect on students' reading comprehension or not. So, this technique can be used for the next time by researcher herself or other teachers if it gives positive effect for

\footnotetext{
${ }^{1}$ Afnita Warni, English Teacher in MAN 1 Padangsidimpuan, Private Interview, October $01^{\text {st }}$ 2016, at 11.00 a.m., in MAN 1 Padangsidimpuan.
} 
students. This reason finally guides the researcher to formulate the title "The Effect of Make a Match Technique on Students' Reading Comprehension at XI Grade of MAN 1 Padangsidimpuan”.

\section{B. LITERATURE REVIEW}

\section{What is Reading Comprehension?}

Reading is comprehension. If students can read the words of a text, but do not understand what they are reading, they are not really reading. ${ }^{2}$ As Hornby says, "comprehension is the power of understanding" 3 . It is the ability to understand a language. Richard says that comprehension is the process by which a person understanding the meaning of written or spoken language clearly. ${ }^{4}$ Besides that, Roebl says that reading comprehension is an ability to understand what the readers read where words have context and texts have meaning. ${ }^{5}$ In addition, David Nunan says that reading comprehension is the instruction program, more emphasis and time may be placed on testing reading comprehension than on teaching reader how to comprehend. ${ }^{6}$ From the definitions, it can be concluded that reading comprehension is mental process in which the readers try to understand the meaning in the text by interpreting what have been read in order to find the idea given by the writers.

\section{How to Asses Reading Comprehension?}

Assessment is a tool to measure how far the students ability and comprehension of the material. ${ }^{7}$ Wadswoth states that there are five types of assessment of reading comprehension. They are:

\footnotetext{
${ }^{2}$ Ellen McIntyre, Nancy Hulan, and Vicky Layne, Reading Instruction for Diverse Classroom, (New York: The Guilford Press, 2011), p. 113-114. 1995), p. 324.

${ }^{3}$ A. S. Hornby, Oxford Advanced Learner's Dictionary, (New York: Oxford University Press, 2000), p. 54.

${ }^{4}$ Richard A. Renandya, Language Teaching Methodology, (Cambridge: Cambridge University,

${ }^{5}$ K. M. Roebl, Developing Reading Comprehension Skill in EFL University Level Student, (Taiwan: St. Jhon's University, 2003), p. 177.

${ }^{6}$ David Nunan, Design Task for the Communicative Classroom, (United Kingdom: Cambridge University Press, 1988), p. 69.

'J. Michael O' Malley and Lorraine Valdez Pierce, Autentic Assessment for English Language Learners, (America: Addision-Wesley Publishing Company, 1996), p. 98.
} 
a. Literal comprehension, entails understanding the information that is explicit in the reading material.

b. Inferential comprehension, means interpreting, synthesizing, or extending the information that is explicit in the reading material.

c. Critical comprehension, requires analyzing, evaluating, and making judgments responses to the material read.

d. Affective comprehension, involves a reader's personal and emotional responses to the reading material.

e. Lexical comprehension, means knowing the meaning of key vocabulary words. ${ }^{8}$

So, in assessing reading comprehension, there are some indicators.

The indicators are students able to:

a. Identify the topic from the text.

b. Identify the main ideas from the text.

c. Identify information that needed from the text.

d. Understand the vocabulary from the text.

e. Give conclusion from the text.

There are some techniques to test reading comprehension, like; multiple choice, short answer questions, cloze task, fill-in-the-blank, and so on, to measure students' reading comprehension. But, in this research, the researcher choose the multiple choice question. A multiple choice question test item is usually set out in such a way that candidate is required to select the answer from a number of given options, only one of which is correct. The marking process is totally objective because the marker is not permitted to exercise judgment when marking the candidate's answer, agreement has already been reached as to the correct answer to each item. ${ }^{9}$

So, in advantages of multiple choice test are the answer have a clear because just there is one the answer of the question, save a time to correct, and easy to give a score of students based on true or false answer, whereas the disadvantages difficult to make a multiple choice answering and generally students just make a guess to answer the question.

\footnotetext{
${ }^{8}$ Wadsworth, Assessment: In Special and Inclusive Education, Eleventh Edition, ( USA: Cengage Learning Press, 2010), p. 196.

${ }^{9}$ Cyrill J. Weir, Communicative Language Testing, (New York: Prentice Hall, 1990), p. 43.
} 


\section{Material of Reading Comprehension}

There are many materials in teaching reading comprehension. One of them is genre text. So, the English learner can learn or understand of subject matter while reading a passage, listening to a spoken English, and produce it when do speaking or writing activities. There are some kinds of genre text in reading comprehension. They are:
a. Descriptive Text
b. Report Text
c. Narrative Text
d. Recount Text
e. Spoof Text
f. Exposition Text
g. Anecdote Text
h. Discussion Text
i. Explanation Text ${ }^{10}$

Based on the some kinds of genre text above, it is relevant with English lesson syllabus of Indonesian curriculum that places these four activities within it. The book uses in MAN 1 Padangsidimpuan is Look Ahead Book 2. This book consists of many reading comprehension buildings, such as genre text, they are Report text, Narrative, and Exposition text (Analytical-Hortatory). ${ }^{11}$ So, in this research the researcher uses two kinds of genre text and the two kinds that appropriate with material of students' English book in first semester at grade XI of MAN 1 Padangsidimpuan. They are Report text, and Narrative text. There are some examples of material reading comprehension in MAN 1 Padangsidimpuan, they are:

\section{a. Example of Report Text}

Read the situation below and choose the best answer for the questions. Sometimes, more than one answer is possible!

It was the first day of the English class and the teacher was introducing himself. He wrote his full name, Allan Jones, on the board and said, "My name is Alan Jones. If you like, you can use

\footnotetext{
${ }^{10}$ Otong Setiawan Djuharie, Genre, Dilengkapi 700 Soal Uji Pemahaman, (Bandung: CV. Yrama Widya, 2007), p. 26.

${ }^{11}$ Th. M. Sudarwati and Eudia Grace, Look Ahead Book 2; An English Course for Senior High School Students Year XI, (Jakarta: Erlangga, 2007), p. 2-154.
} 
'Mr' with my name. Now I'd like you to tell me your names. Let's start with you," he said, indicating a young girl in the front row.

"My name is Liliana Castro, but you can call me Lily, Teacher."

Then the teacher said, "OK. I'll call you Lily, but please don't call me 'Teacher'. Please call me Alan or Mr. Jones."

Lily looked confused, but the teacher ignored her and continued to ask the students to introduce themselves.

1) What is the topic of text?
a. Social Behavior
b. Classroom Behavior
c. Behavior
d. Teacher

2) Why did Liliana call Alan Jones 'Teacher'?
a. She didn't know his name
b. She was trying to show respect
c. She couldn't pronounce his name
d. She felt confused

3) Why did Alan Jones ask Liliana not to call him 'Teacher'?
a. He didn't really like being a teacher
b. He wanted to be friendly
c. In his country, only very young pupils call their teacher 'Teacher'
d. He thought Liliana was being rude ${ }^{12}$

\section{b. Example of Narrative Text}

Read carefully the following tetx!

\section{The Lion and the Mouse}

One, when a lion was asleep, a little mouse began running up and down upon him; this soon awakened the lion, who placed his huge paw upon him, and opened his big jaws to swallow him. "Pardon, O king," cried the little mouse, "Forgive me this time, I shall never forget it; who knows but what I may be able to do you a turn some of these days?"

The lion was so tickled at the idea of the mouse being able to help him, that he lifted up his paw and let him go.

Some time after, the lion was caught in a trap and the hunters, who desired to carry him alive to the king, tied him to a tree while they went in search of a wagon to carry him on.

Just then the little mouse happened to pass by and see the sad plight in which the lion was. He went up to the lion and soon

\footnotetext{
${ }^{12}$ Ibid., p. 20.
} 
gnawed away the ropes that bound the king of the beasts. "Wasm't I right?", said the little mouse.

Answer the question based on the text you have read!

1) What was the lion doing when the mouse tran up and down upon him?

2) What happened to the lion sometime after?

3) What is the message of the story?

4) Who are the main participants of the story?

5) How did he overcome his problem ${ }^{13}$

Based on the explanations above, reading comprehension is understanding the meaning of text, and consequence associated with the act of reading, students know that reading comprehension is very important, cause comprehension is the process by which a person understanding the meaning of written or spoken language. In conclusion, reading comprehension is the ability of the reader to understanding of the text and comprehend the meaning of the text.

\section{Defining Make a Match Technique}

Make a Match is a technique to teach all subject matter by using cards. The cards consist of question and answer form that appropriate with a topic or subject matter in learning process. Make a Match technique was developed by Lorna Curran in 1994s. One of the profits of this technique is the students look for their partner while learning a concept or topic in interesting situation. This technique can be applied in all of the subject matter and grade level. ${ }^{14}$ Besides it, Arifah and Kusumarasdyati states that Make a Match is one of the teaching techniques which can be used in cooperative learning. The Make a Match technique is a kind of game where students have to find their partner. ${ }^{15}$ In addition, Make a Match technique is interesting technique which used to review the material given before. But, the new material can also be taught in this technique with note, the students

\footnotetext{
${ }^{13}$ Ibid., p. 135.

${ }^{14}$ Anita Lie, Cooperative Learning, (Jakarta: PT. Grasindo, 2008), p. 55.

${ }^{15}$ Arifah and Kusumarasdyati, The Effectiveness of Make a Match Technique for Teaching Writing Descriptive Text to the Seventh Graders of SMP N 1 Karangbinangun Lamongan, retrieved from http://www.ejournal.unesa.ac.id/article/3061/58/article/pdf., on May $24^{\text {th }}, 2017$ at $05.30 \mathrm{am}$.
} 
given exercise to study the topic that will be taught first, so when enter the class they have had knowledge. ${ }^{16}$ From these explanations, it can be concluded that Make a Match technique is a kind of technique to teach reading comprehension that uses cards which contains question and answer card about a topic or material of learning process. This technique can be taught in groups, pairs or in individual activities. Thus, this technique assumes that the students can more active and enjoy to study by using Make a Match technique.

\section{The Advantages and Disadvantages of Make a Match Technique}

The advantages of Make a Match technique as follow:

a. It can increase student's learning activity for their cognitive and physic.

b. It can create a joyful learning because it is like a game.

c. It can increase student's comprehension about the material, because the materials of teaching are easy.

d. It can increase student's motivation in learning.

e. It can increase the students' creativity through matching the cards.

f. It can help avoid students being bored during the teaching learning process.

g. All of students in the class more active. ${ }^{17}$

Based on the quotations above, the advantages of Make a Match technique are can increase students' learning activity for their cognitive and physic, can create a joyful learning and the students will not feel so bored or be afraid of making a mistake in pronouncing a word or sentence, can increase students' comprehension about the material because the material of teaching become easy, and all of students in the class more active.

Besides that, there are some disadvantages of Make a Match technique, they are:

a. Each student has a different ability, so they cannot deliver their ideas fluently.

\footnotetext{
${ }^{16}$ Asri Pratiwiningsih, The Effectiveness of Make a Match Technique in Teaching Reading Comprehension Report Text at XI Grade SMA Negeri 1 Ngimbang Lamonan, retrieved from http://www.ejournal.stkipjb.ac.id/index.php/AS/article/download/225/161/pdf., on October 14 ${ }^{\text {th }}, 2016$ at $04.20 \mathrm{pm}$

${ }^{17}$ Ibid., p. 65.
} 
b. The situation of this class is noisy. ${ }^{18}$

\section{RESEARCH METHODOLOGY}

\section{The Place and Time of the Research}

The research was done at MAN 1 Padangsidimpuan. It is located on Sutan Soripada Mulia Street, No. 31 C Padangsidimpuan Utara. Then, The time of the research was from October $03^{\text {rd }}, 2016$ until September $25^{\text {th }}, 2017$.

\section{The Research Design}

The kind of this research was quantitative research with experimental method. Experimental research is the type of research that can test hypotheses to establish cause and effect relationships. ${ }^{19}$ It meant that the experimental research has purpose to find out the significant effect of a treatment on dependent variable. Dependent variable here was reading comprehension and the treatment is Make a Match technique.

Based on using control and experimental class, the research design that was used 'true experimental design'. The design which used was PretestPosttest Control Group Design. It meant there were two classes chosen randomly, then gave pre-test to know the basic condition of the two classes. Next, after teaching reading comprehension with different implementation, the both of classess were given post test. The result of the test was compared to know the different effect of treatment to experimental class. The research design of this research can be seen in the following table:

Table 1. Research Design (Pretest-Posttest Control Group Design)

\begin{tabular}{|c|c|c|c|}
\hline $\mathrm{R}$ & $\mathrm{O}_{1}$ & $\mathrm{X}$ & $\mathrm{O}_{2}$ \\
\hline $\mathrm{R}$ & $\mathrm{O}_{3}$ & & $\mathrm{O}_{4}$ \\
\hline
\end{tabular}

Where:

$\mathrm{R}=$ The sample of the research

$\mathrm{O}_{1}=$ Pretest in experimental class

$\mathrm{O}_{2}=$ Posttest in experimental class

$\mathrm{X}=$ Treatment

$\mathrm{O}_{3}=$ Pretest in control class

\footnotetext{
${ }^{18}$ Istarani, Op.Cit., p. 66.

${ }^{19}$ L.R Gay and Peter Airasian, Educational Research: Competencies for Analysis and Application, (America: Prentice Hall, 2000), p. 367.
} 
$\mathrm{O}_{4}=$ Posttest in control class ${ }^{20}$

\section{The Population and Sample}

a. Population

Table 2. The Population of the grade XI MIA students of MAN 1 Padangsidimpuan

\begin{tabular}{|c|c|c|}
\hline No. & Class & Students \\
\hline 1 & XI MIA 1 & 40 \\
\hline 2 & XI MIA 2 & 42 \\
\hline 3 & XI MIA 3 & 40 \\
\hline 4 & XI MIA 4 & 40 \\
\hline 5 & XI MIA 5 & 42 \\
\hline 6 & XI MIA 6 & 40 \\
\hline 7 & XI MIA 7 & 42 \\
\hline 8 & XI MIA 8 & 42 \\
\hline \multicolumn{2}{|c|}{ Total } & $\mathbf{3 2 8}$ \\
\hline
\end{tabular}

Sources: Total of students at XI MIA Grade of MAN 1

Padangsidimpuan T.A 2017-2018

\section{b. Sample}

In this research, the researcher used simple random sampling. Before use simple random sampling, the researcher used normality and homogeneity test. Based on the explanation above, the researcher had given pre-test to three classes (XI MIA 2, XI MIA 3, and XI MIA 4), to know whether the samples are homogenous and normal or not. After calculating the data, the researcher had found that the three classes were homogenous and normal (see appendix 17 and 18). So, the researcher chose two classes as the sample. These two classes had same total of students. They were XI MIA 3 and XI MIA 4. The both classes consisted of 40 students. Here was the sample:

Table 3. Sample of the Research

\begin{tabular}{|c|c|c|}
\hline Sample & Class & Total \\
\hline Experimental Class & XI MIA 3 & 40 \\
\hline Control Class & XI MIA 4 & 40 \\
\hline
\end{tabular}

\footnotetext{
${ }^{20}$ Sugiyono, Metode Penelitian Pendidikan; Pendekatan Kuantitatif, Kualitatif, dan R\&D, (Bandung: Alfabeta, 2008), p. 112-113.
} 


\section{FINDINGS}

After calculating the data of post-test, researcher has found that post-test result of experimental and control class is normal and homogenous. The data would be analyzed to prove the hypothesis. It used formula of t-test. Hypothesis of the research was "Make a Match technique has significant effect on reading comprehension at XI grade of MAN 1 Padangsidimpuan". The calculation can be seen on the appendix 22 and 23. The result of t-test was as follow:

Table 4. The Result of T-test from the Both Averages

\begin{tabular}{|c|c|c|c|}
\hline \multicolumn{2}{|c|}{ Pre-test } & \multicolumn{2}{c|}{ Post-test } \\
\hline $\mathrm{t}_{\text {count }}$ & $\mathrm{t}_{\text {table }}$ & $\mathrm{t}_{\text {count }}$ & $\mathrm{t}_{\text {table }}$ \\
\hline 0.740 & $0^{2.00}$ & $9^{3.00}$ & 2.000 \\
& 0 & 9 & \\
\hline
\end{tabular}

The test hypothesis have two criteria. First, if $t_{\text {count }}<t_{\text {table }}, H_{0}$ is accepted. Second, $t_{\text {count }}>t_{t a b l e}, H_{a}$ is accepted. Based on researcher calculation in pre test, researcher found that $t_{\text {count }} 0.740$ while $t_{\text {table }} 2.000$ with opportunity $(1-\alpha)=1$ $5 \%=95 \%$ and $\mathrm{dk}=\mathrm{n}_{1}+\mathrm{n}_{2}-2=40+40-2=78$. Cause $\mathrm{t}_{\text {count }}<\mathrm{t}_{\text {table }}(0.740<$ 2.000), it meant that hypothesis $\mathrm{H}_{\mathrm{a}}$ was rejected and $\mathrm{H}_{0}$ was accepted. So, in pre test, the two classes were same. There is no difference in the both classes. But, in post test, researcher found that $t_{\text {count }} 3.009$ while $t_{\text {table }} 2.000$ with opportunity $(1-\alpha)$ $=1-5 \%=95 \%$ and $\mathrm{dk}=\mathrm{n}_{1}+\mathrm{n}_{2}-2=40+40-2=78$. Cause $\mathrm{t}_{\text {count }}>\mathrm{t}_{\text {table }}(3.009>$ 2.000), it meant that hypothesis $\mathrm{H}_{a}$ was accepted and $\mathrm{H}_{0}$ was rejected. The calculation can be seen on the appendix 23. In this case, the mean score of experimental class by using Make a Match technique was 75.23 and mean score of control class was 68.98 that was taught by using conventional technique. So, there was the significant effect of Make a Match technique on students' reading comprehension at XI grade of MAN 1 Padangsidimpuan.

\section{E. CONCLUSION}

Based on the result of the research, the conclusions of this research are:

1. Before using Make a Match technique, the students' mark in reading comprehension was unsatisfied. The mean score of pre-test for the experimental class that used Make a Match technique was 64.13. 
2. After using Make a Match technique, the mean score of experimental class was higher than before using Make a Match technique. The mean score of post-test for the experimental class was 75.23.

3. The researcher found the research result of t-test where $t_{0}$ was higher than $t_{t} \cdot t_{0}$ was 3.009 and $t_{t}$ was $2.000(3.009>2.000)$. It meant that there was a significant effect of Make a Match technique on students' reading comprehension at XI grade of MAN 1 Padangsidimpuan where $\mathrm{H}_{\mathrm{a}}$ was accepted and $\mathrm{H}_{0}$ was rejected.

\section{REFERENCES}

Agus, Suprijono. Cooperative Learning, Teori dan Aplikasi PAIKEM. Yogyakarta: Pustaka Pelajar. 2012.

Anas, Sudjiono. Pengantar Statistik Pendidikan. Jakarta: PT. Raja Grafindo Persada. 1995.

Anita, Lie. Cooperative Learning. Jakarta: PT. Grasindo. 2008.

Arifah and Kusumarasdyati. The Effectiveness of Make a Match Technique for Teaching Writing Descriptive Text to the Seventh Graders of SMP N 1 Karangbinangun Lamongan. Retrived from http://www.ejournal. unesa.ac.id/article/3061/58/article /pdf., on May $24^{\text {th }}, 2017$ at $05.30 \mathrm{am}$.

Brown, H. Douglas. Teaching by Principle: An Interactive Approach to Language Pedagogy. USA: Prentice Hall.

Deriden, Jhon. Conventional Technique. Retrieved from http://www.britania. com/Ebchecked/topic/421797/nnucler-strategy/52993/conventional-strategy. on December $24^{\text {th }}, 2016$ at 10.00 p.m.

Dupuis, Mary M. And Linda H. Merchant. Reading Across the Curriculum: A Research Refort for Teachers. Bloominton, Indiana: Edinfo Press. 1993.

Gattegno, Caleb. Teaching Foreign Languages in Schools. New York: Educational Solutions. 1972.

Gay, L. R., and Peter Airasian. Educational Research: Competencies for Analysis and Application. America: Prentice Hall. 2000.

Grabe, William. Reading in a Second Language. Cambridge: Cambridge University Press. 2009. 
Hartono. Statistik Untuk Penelitian. Yogyakarta: Pustaka Pelajar. 2004.

Hudson. The Meaning of Conventional Teaching (Online). Retrieved from http://www.conventional-strategy/topic/54372-strategy., on October, $02^{\text {nd }} 2016$ at $11.30 \mathrm{am}$.

Hornby, A.S. Oxford Advanced Learner's Dictionary of Current English. New York: Oxford University Press. 1995.

Ibrahim and Muslimin. Pembelajaran Kooperatif. Surabaya: Unesa-University Press. 2000 .

Istarani. 58 Model Pembelajaran Inovatif. Medan: Media Persada. 2014.

Miftahul, Huda. Cooperative Learning. Yogyakarta: Pustaka Pelajar. 2012.

McIntyre, Ellen Nancy Hulan, and Vicky Layne. Reading Instruction for Diverse Classroom. New York: The Guilford Press. 2011.

Nanang, Hanafiah. Konsep Strategi Pembelajaran. Bandung: PT. Refika Aditama. 2009.

Nunan, David. Practical English Language Teaching, First Edition. New York: McGraw Hill Inc. 2003.

Design Task For the Communicative Classroom. United Kingdom: Cambridge University Press. 1988.

Nuttall, Christine Elizabeth. Teaching Reading Skills in a Foreign Language. London: Heinemann Educational Books. 1982.

Otong Setiawan, Djuharie. Genre, Dilengkapi 700 Soal Uji Pemahaman. Bandung: CV. Yrama Widya. 2007.

Yrama Widya. 2008.

Intensive Reading Bottom-Up Reading. Bandung: CV.

Otto, Wayne. How to Teach Reading. USA: Wesley Publishing Company. 1979.

O’Malley, J. Michael and Lorraine Valdez Pierce. Autentic Assessment for English Language Learners. America: Addision-Wesley Publishing Company. 1996.

Pham, Thihanh. Learners' and Teachers' Preference for Classroom Activities. Colchester: Essex University Press. 2005.

Renandya, Richard A. Language Teaching Methodology. Cambridge: Cambridge University. 2006. 
Roebl, K.M. Developing Reading Comprehension Skill in EFL University Level Student. Taiwan: St. Jhon's University. 2003.

Syaiful Bahri, Djamarah. Strategy Belajar-Mengajar. Jakarta: PT. Asdi Mahasatya. 2006.

Suharsimi, Arikunto. Dasar-dasar Evaluasi Pendidikan, Edisi 2. Jakarta: Bumi Aksara. 2012.

Prosedur Penelitian Suatu Pendekatan Praktik. Jakarta: PT. Rineka Cipta. 2006.

Sugiyono. Metode Penelitian Pendidikan; Pendekatan Kuantitatif, Kualitatif, dan R\&D. Bandung: Alfabeta. 2008.

Tarigan, Henry Guntur. Membaca Sebagai Keterampilan Berbahasa. Bandung: Aksara. 1990.

Th. M., Sudarwati. and Eudia Grace. Look Ahead Book 2; An English Course for ${ }^{\mathrm{r}}{ }^{\circ} r$ High School Students Year XI. Jakarta: Erlangga. 2007.

Umar, Farooq. The Procedures of Teaching Lecture Technique. Retrieved from http://www.study.lecturenotes.com/social-education/382-lecture-method-ofteaching-definiton-steps-html., on April, $27^{\text {th }} 2017$ at 09.05 a.m.

Vanderstoep, Scott W. and Deirdre D. Johnston. Research Methods for Everyday Life: Blending Qualitative and Quantitative Approaches. San Fransisco: Jossey Bass. 2009.

Wadsworth. Assessment: In Special and Inclusive Education, Eleventh Edition. USA: Cengage Learning Press. 2010.

Weir, Cyrill J. Communicative Language Testing. New York: Prentice Hall. 1990.

Westwood, Peter. Reading and Learning Difficulties: Approach to Teaching and Assessment. Australia: National Library of Australia. 2001. 